\title{
慢性関節リウマチにおける頸椎レ線の経時的変化
}

\author{
島根県立中央病院整形外科 \\ 片山稔・冨 永 積 生 \\ 大内啓 司・豊 海隆 \\ 芦 田一郎・野 田 基 博 \\ 加 藤 圭 彦
}

\section{Radiological Progression of the Rheumatoid Cervical Spine}

by

\author{
Minoru Katayama, Sekio Tominaga, Keiji Ohuchi, \\ Takashi Toyoumi, Ichiro Ashida, Motohiro Noda \\ and Yoshihiko Katho \\ Department of Orthopedic Surgery, \\ Shimane Prefectural Central Hospital
}

\begin{abstract}
86 patients with rheumatoid arthritis (RA) were studied to clarify the radiological progression of the cervical spine. The number of patients without radiological changes decreased from 60 at the time of initial examination to 45 at the final examination in an average duration of 14 years and 3 months. The radiological changes occurred more likely in the upper cervical spine than in the middle or lower cervical spine. Atlanto-axial subluxation was one of the characteristic early features of RA, which was detected in $8.1 \%$ of the patients, increased over 10 years period markedly and found in $48 \%$ of the patients in the 3rd decade of RA. Odontoid erosion was also the most common radiological change detected in early RA and the change increased in the 3rd and 4th decades of RA.

In the middle or lower cervical spine, disc narrowing had a significant increase in the 3rd decade of RA. Subaxial subluxation increased gradually in frequency with increased disease duration. Apophyseal erosions also showed a tendency to increase gradually with increasing duration of the disease.
\end{abstract}

\section{はじめに}

慢性関節りウマチ (以下 RA) において頸椎病変は多 くの症例で認められる。奉髄あるいは脳幹部における RA の破壊性変化は, 四肢麻瘒や突然死を含む重大な神 経学的症状を引き起こす可能性があり, 四肢末梢関節 の変化のみでなくこの部に対しても注意を払うべきで ある.レ線で認められる頸椎変化は, RA の罹病期間に 関係して進行するとされている ${ }^{12)}$. しかし, 実際の症 例における頸椎変化の進行は必ずしも画一的でない. 今回, RA における頸椎レ線の経時的変化について検
討し報告する。

\section{対象と症例}

対象とした症例は, American Rheumatism Association (AAS)による RA のクライテリア4) を満たした 86 例であった。そのうち女性は 71 例で男性は 15 例であ った. 年齢分布は 28 歳から 72 歳で, 平均 55.3 歳, 罹 病期間は 4 年 3 力月から 37 年におよび平均 14 年 3 力 月であった (表 1 ).

頸椎レ線は, 原則的に前後, 側面前屈位, 中間位, 後屈位および両斜位の 6 方向の撮影を行い, これに加 
表 1 対

象 (86例)

\begin{tabular}{|c|c|c|c|c|c|}
\hline & & \multirow{3}{*}{\multicolumn{4}{|c|}{$\begin{array}{l}\text { 男性 } 15 \text { 例, 女性 } 71 \text { 例 } \\
28 \text { 才 } 72 \text { 才平均 } 55.3 \text { ) } \\
4 \text { 年 } 3 \text { 力月 37年 (平均 } 14 \text { 年 } 3 \text { 力月 }\end{array}$}} \\
\hline & 令 & & & & \\
\hline 罹 病 期 & & & & & \\
\hline \multirow[t]{2}{*}{ Stage } & & I & 8例 & II & 13例 \\
\hline & & III & 37例 & IV & 28例 \\
\hline
\end{tabular}

表 2 最終調査時におけるレ線変化

\begin{tabular}{|c|c|c|}
\hline \multicolumn{3}{|l|}{ Upper cervical spine } \\
\hline \multicolumn{3}{|c|}{ Atlanto-axial subluxation (AAS) } \\
\hline anterior AAS & \multicolumn{2}{|c|}{ : $32 \operatorname{cases}(37.2 \%)$} \\
\hline lateral AAS & $: 3$ & $(3.5)$ \\
\hline posterior AAS & $: \quad 1$ & $(1.2)$ \\
\hline Vertical subluxation & $: 15$ & $(17.2)$ \\
\hline Occipito-atlanto & & \\
\hline erosion & $: 20$ & $(23.3)$ \\
\hline $\begin{array}{l}\text { Lateral atlanto-axial } \\
\text { erosion }\end{array}$ & $: 33$ & $(38,4)$ \\
\hline Odontoid erosion & : 30 & $(34.9)$ \\
\hline Thin dens & $: 6$ & $(7.0)$ \\
\hline \multicolumn{3}{|c|}{ Middle and lower cervical spine } \\
\hline Subaxial subluxation & $: 15$ & $(17.4)$ \\
\hline single level & $: 9$ & $(10.5)$ \\
\hline multiple levels & $: 6$ & $(7.0)$ \\
\hline Apophyseal erosion & $: 13$ & $(15.1)$ \\
\hline Apophyseal fusion & $: 4$ & $(4.7)$ \\
\hline Disc narrowing & $: 24$ & $(27.9)$ \\
\hline End-plate erosion & $: 13$ & $(15.1)$ \\
\hline
\end{tabular}

え環軸椎部の病変が疑われた場合には開口位のレ線が 追加された.

さらにこれらのレ線で不明瞭な病変は断層撮影, CT, およびMRI を補助診断とした。

\section{結果}

\section{最終調查時レ線変化（表 2 ）}

平均罹病期間 14 年 3 力月におけるレ線変化では,上 位頸椎において中下位頸椎より多くの変化を認めた。

上位頸椎変化のうち環軸椎前方覀脱臼（以下 AAS） は, $37.2 \% に$ 認められ，もっとも多く見られた変化の 一つであった．環軸椎部に関しては種々の方向に対す る覀脱臼も見られ，側方亜脱臼は $3.5 \%$ ，また後方亜 脱臼も $1.2 \%$ に認められた.垂直性亜脱臼は $17.2 \%$ で あった、関節びらんは側方環軸椎関節にもっとも多く 見られ $38.4 \%$ ，また後頭環軸椎関節のびらんは 23.3 \%であった。

中下位頸椎においては, 軸椎下覀脱臼が $17.4 \%$ に認 められた.これらのうち一椎間での亜脱臼は $60 \%$ \%

\section{表 3 経時的レ線変化}

\section{上位寡椎の経時的变化}

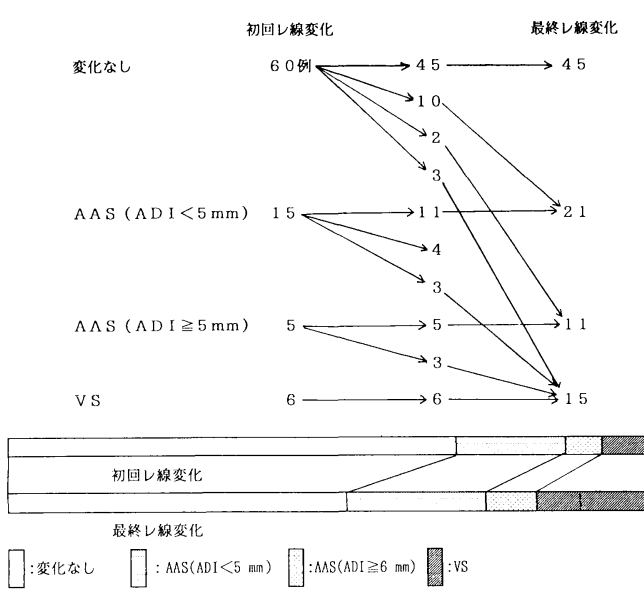

\section{中下位䡩椎 経時的変化}

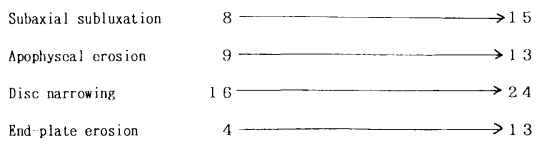

り, 多椎間での亜脱臼は $40 \%$ であった。これら軸椎下 亜脱臼を認めた症例のうち $46.7 \%$ AAS を認め, ま た $20 \%$ では AASに加え垂直性亜脱臼を伴っていた。 endplateのびらんは全レベルにわたり $15.1 \%$ \%認めら れたが, 多くの症例ではこの部位での椎間板の狭小化 が見られた。

結果的には全症例の $47.7 \%$ 頸椎変化が認められ た.

\section{経 時 的 変 化}

初回調査時に頸椎変化を認めなかった $69.8 \%$ の症例 は最終調查時には $52.3 \%$ と減少し結果的には 17.5 \%に頸椎レ線変化の進行を認めた.

このうち, AAS は $23.3 \%$ から $37.2 \%$ に また垂直 性亜脱臼は $7 \%$ から $17.2 \%$ へと増加した。

中下位頸椎では, 軸椎下亜脱臼が $9.3 \%$ から $17.2 \%$ に，また椎間板の狭小化は $18.6 \%$ から $27.8 \%$ に増加 した（表 3 ).

各変化の出現頻度を 10 年毎の罹病期間に分けて検討 してみると, 10 年末満の初期の症例では歯突起のびら んが $10.5 \%$ もっとも多く見られた変化であった。こ の変化は罹病期間が 20 年を越えると著しい増加を認め 
表 4 罹病期間とレ線変化

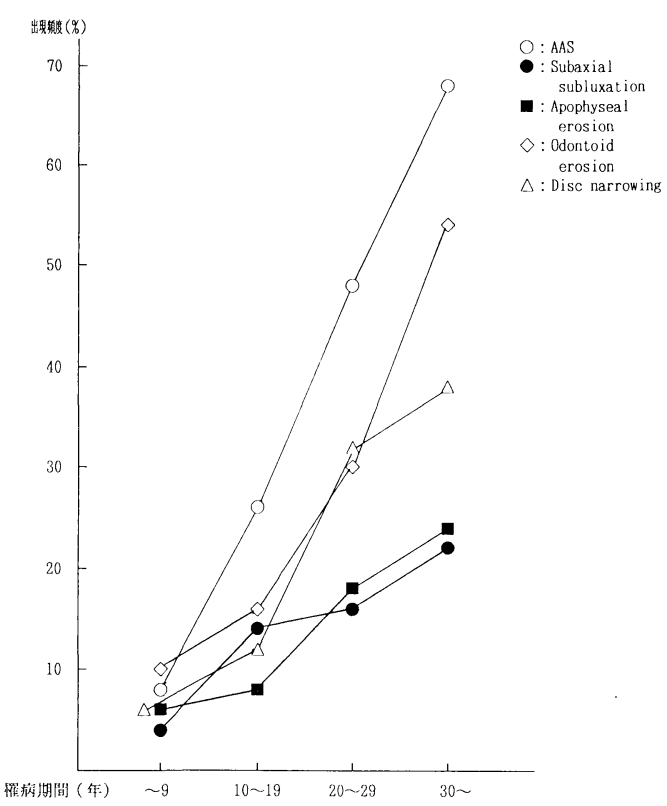

表 5 手のレ線における Stage と頸椎罹患の関係

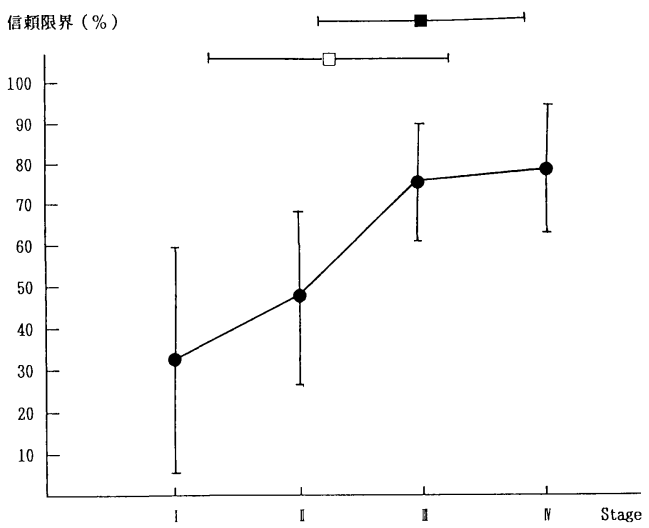

口:レ線的買系なし Stage $=2.243 \pm 0.983$

【：レ線的異禁あり Stage $=3.075 \pm 0.831$

信赖限界 $(p<0.05)$

Stage 1： $0.055<$ 信赖限界 $<0.572$

Stage II : $0.255<1<0.647$

Stage II: $: 0.618<, \quad<0.902$

Stage N: $0.631<, \quad<0.940$

た.

AAS は RA の特徵的変化と考えられているが, 罹病 期間が 10 年末満の症例では $8.1 \%$ 頻度が 10 年を越 える症例ではその頻度は著しく増加し, 20 年を越える
症例では $48 \%$ に認められるようになった。

椎間板狭小化は初期（罹病期間 10 年末満）には $6 \%$ に見られたのみであったが, 20 年を越える時期より著 しい増加を認めた。

軸椎下亜脱臼は初期には $4 \%$ に認められた変化であ ったが,この変化はその後罹病期間の経過とともに増 加していった.アポフィーゼ関節の変化も同様な傾向 を認めた（表 4 ）.

RA における障害好発部位の一つである手のレ線変化 はRAの $68.5 \%$ (5) の高頻度に認められている.この部 の stage と頸椎レ線変化の関係を調べてみると stage III以上の症例では $5 \%$ の危険率で $60 \%$ 以上の症例に頸 椎変化が認められ, 頸椎レ線変化は末梢関節変化と密 接な関係があると考えられた（表 5 ).

\section{考察}

頸椎における 32 の滑膜関節の存在はこの部を RAの 障害好発部位の一つとしている.RAにおける頸椎罡患 の頻度は対象症例により異なっているが, Meikle らは 333 患者の検討で $50 \%$ と報告し, Bland ら ${ }^{3)}$ は $86 \%$ と いう高頻度を報告している。

RA の頸椎でもつとも多く認められる変化の一つとし てAAS があげられるが, 今回の検討においても発症 2 年ですでに AAS が認められ，この知見を支持するもの である(図 1 ).

AASの発生のメカニズムは実験的に検討され横靱帯 の切離のみでは環軸間距離を $4 \sim 5 \mathrm{~mm}$ 拡大させるに 過ぎないことより, AAS の発生に対してはもっと広範 な破壊が必要であると考えられる6).

RA における頸椎レ線の進行は中下位頸椎より上位頸 椎に優位であるとされるが, 今回の検討でもそのよう に考えられた。

今回の検討で, 経過中 8 患者は垂直性亜脱臼を生じ た.このうち 2 患者のみが AAS の見られなかった症例 であり, 残り 6 例では AAS より進行し, 垂直性亜脱臼 は通常 AAS より進展すると考えられた. 歯突起のびら んもまた AAS の発生に大きな関与をしていると考えら れた (図 2 ).

中下位頸椎においては, 椎間板狭小あるいは endplate のびらんは種々のレベルで不安定性や亜脱臼を伴 って認められた.今回の検討では end-plate のびらんは 軸椎下亜脱臼を伴った症例および伴わない症例で同頻 度に認められた（亜脱臼例：34\%,非亜脱臼例：32\%) 


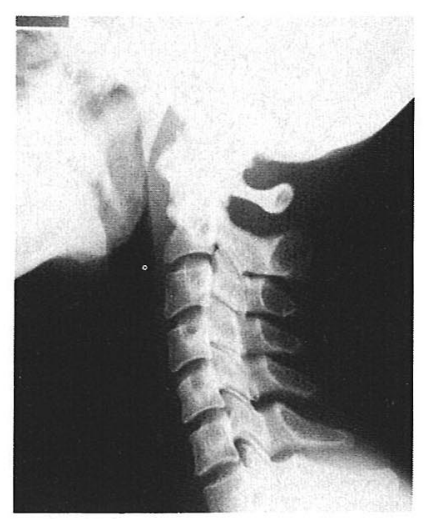

(A)

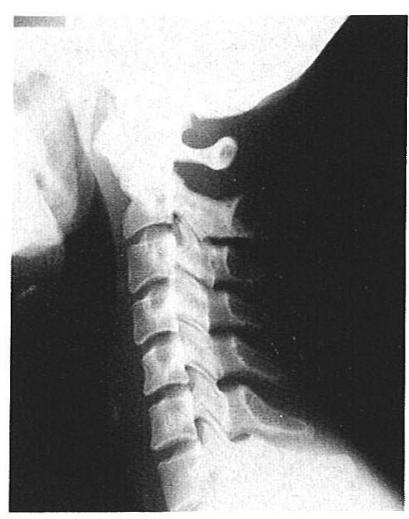

(B)

図 128 歳女性。

(A) 発症 2 年ですでに AASを認める.

(B) その 2 年 5 力月後 $\mathrm{ADI}$ の拡大はあるが, 他の部位には変化を認めない.
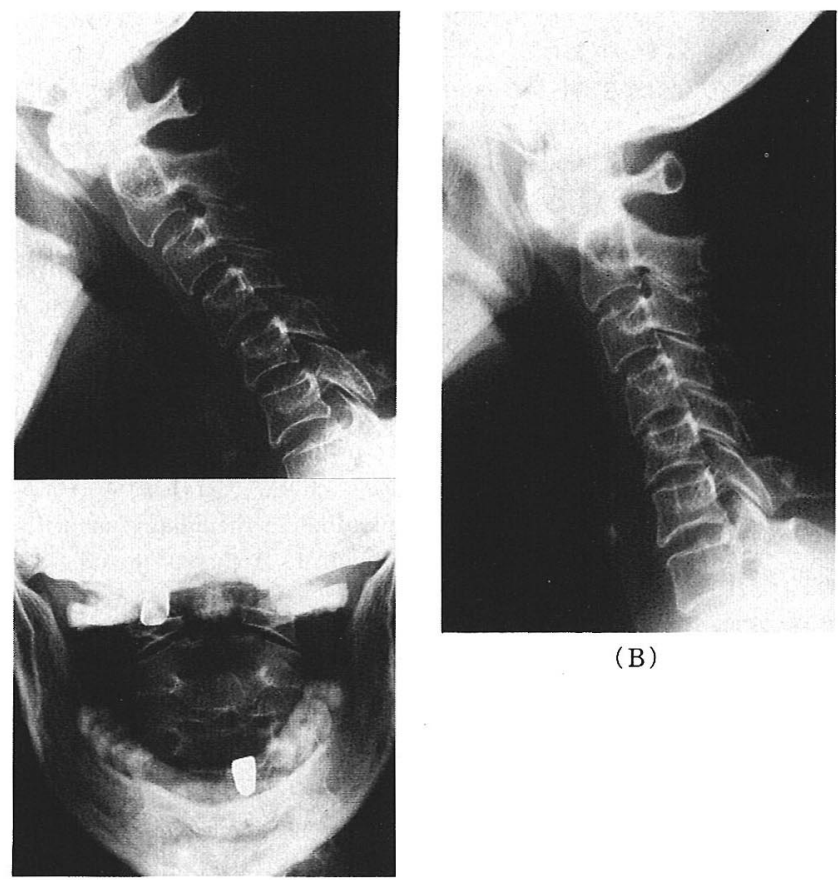

(B)
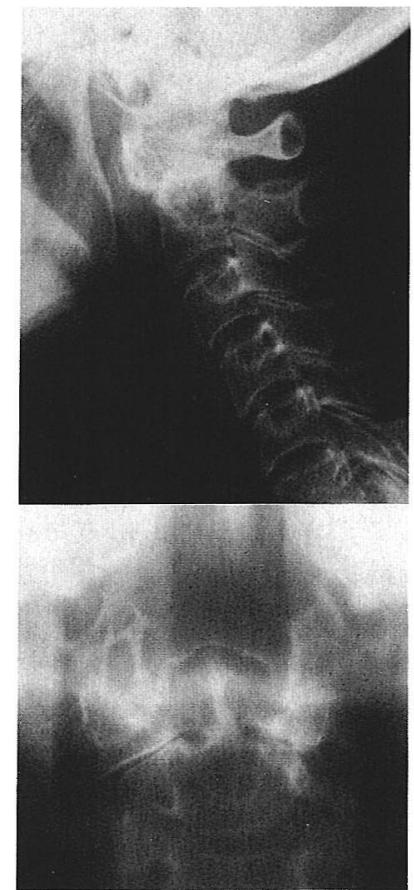

(A)

(C)

図 268 歳女性.

(A) 発症 11 年では開口位においても歯突起には大きな変化は認められない.

(B) 発症 16 年になると歯突起前縁のびらんとともに AAS を認める.

(C) 発症 19 年においては thin dens が認められ, 左側方環軸関節のびらんと環軸関節狭小化を認め, downward luxation が認められる。 


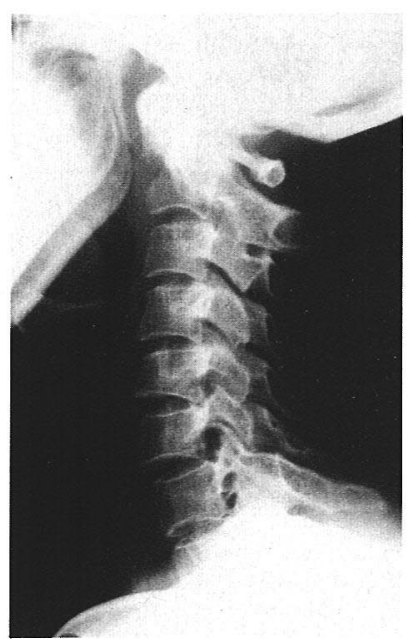

(A)

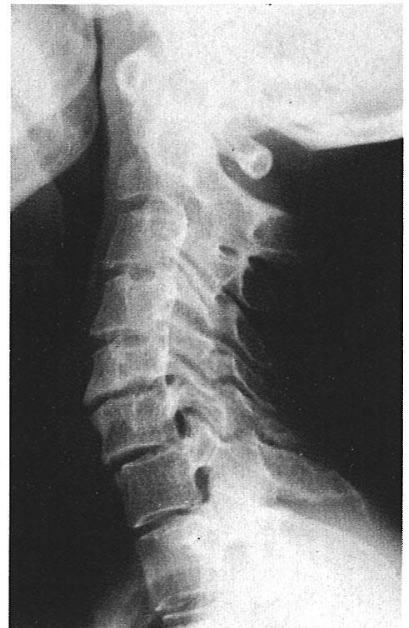

(B)

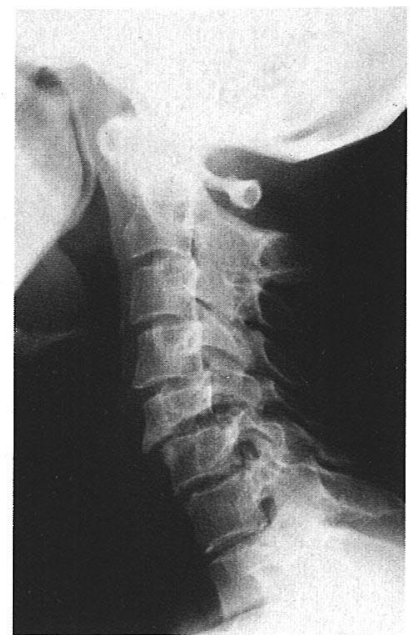

(C)

图 3 - 42 歳女性,

(A) 発症 10 年.このレ線ではC 5 の圧迫骨折様変化を認める。

(B) 発症 14 年では (A) で見られる上位頚椎変化は進展を見ないが, apophyse 関節変化とともに end-plate のびらんを認め椎間板の狭小を認める。

（C）さらに，発症 19 年に扔いては C5/6において subaxial subluxation を呈し，椎体破壊が見られる。位 頸椎変化は不変である。

一方，アポフィーゼ関節びらんは亜脱臼グループに優 位であった（亜脱臼例： $60 \%$ ，非垔脱臼例：34\%)し たがって軸脊椎下亜脱臼の発生にはアポフィーゼ関節 のびらんが大きな役割を果たしていると思われた（図 $3)$.

RA における頸栦病変は必ずしも神経学的症状と一致 するものではなく，このため RA 患者の多くにとって は頸椎病変よりむしろ四肢末梢関節の疼痛や不自由が より重要な問題であることが多いが，剖検時に初めて 診断された症例の報告も7 あり, RA の頸椎病変におけ る秘められた危険性は常に銘記すべきであると思われ る.

\section{文献}

1) Bland, J, H., Davis, P. H. London, M. G. et al: Rheumatoid arthritis of cervical spine. Arch. Intern. Med., 112: 829-898, 1963.

2) Bland, J. H., Van Buskirk, F. W., Tampas, J. P., et al: A study of roentgenologic criteria for rheumatoid arthritis of the cervical spine. A. J. R., 95: 949-954, 1965

3) Bland, J. H., Rheumatoid arthritis of the cervical spine. J. Rheumatol., 1: 319-342, 1974.

4) Frank, C. A., Steven, M. E., Daniel, A. B., et al:
The American Rheumatism Association 1978 revised criteria for the classification of rheumatoid arthriti. Arthritis Rheum., 31 : 315-324, 1988.

5）片山 稔・冨永積生・伊達和友・他：慢性関節りウマ チの手のレ線の検討。島根県中病医誌，12(1)：49-53, 1985.

6) Martel, W. Page, J. W., : Cervical vertebral erosions and subluxations in rheumatoid arthritis and ankylosing spondylitis. Arthritis rheum., 3: 546$556,1960$.

7) Martel, W., Abell M. R., : Fatal atlanto-axial luxation in rheumatoid arthritis. Arthritis rheum., 6 224-231, 1963.

8) Meikle, J., Wilkinson, M., : Rheumatoid involvement of the cervical spine. Ann. Rheum. Dis., 30: $154-161,1971$
質 問
宮崎医科大学 田島直也
(1) 垂直性亜脱臼例で，始め環軸椎亜脱臼が明らか に先行していた症例は何例ありましたか。

(2) 垂直性覀脱臼例では環軸椎の stability になって いましたか。

解 答島根県立中央病院 片山 稔

(1) 今回の検討における垂直性亜脱臼の進行は 8 例 
にみられ，そのうち 6 例が環軸椎亜脱臼より進行して いった.

(2) 今回の症例では 8 例に spontanous fusion を認 め, これらの症例ではその後の進行が停止した。

\section{質 問 熊本整形外科病院 栄 輝己}

(1) 上位頸椎進行停止例のレ線との特徵があります か.

(2) 進行の程度に男女差がありますか.
解 答 島根県立中央病院 片山 稔

(1) 単純レ線においては確認し難いか, 断層撮影お よびCTで spontanous fusion を呈した症例を進行停 止症例とした.

(2) 今回の検討ではとくに男女差は認めなかったが， 進行の早い症例は RA の炎症が持続し末梢関節破壊の 強い症例に多くみられた。 